\title{
Federal Funding in the South: Bringing Home the Bacon, but Where's the Beef?
}

\author{
Richard J. Reeder, Samuel D. Calhoun, and Faqir S. Bagi*
}

\begin{abstract}
The South receives more federal funding per capita than other regions, but much of the South's funding advantage comes from the defense and space industries and other functions serving national rather than regional or local objectives. In contrast, most programs designed to achieve regional and local development objectives do not particularly benefit the South, and the nonmetro South gets relatively fewer of many of these programs then nonmetro areas nationwide. Metro areas generally receive more federal funds per capita than nonmetro areas, but this metro-nonmetro gap is larger in the South than elsewhere in the country. Another nationwide pattern that is particularly present in the South is that federal spending tends to favor higher-income areas, especially among metro areas. While federal spending may help mitigate growth disparities nationwide, we found no evidence of this in the South.
\end{abstract}

\section{INTRODUCTION}

As the South's share of U.S. population has grown from 32.7 percent in 1980 to 35.2 percent in 1997 (Beale 1999, p. 21), its political influence in Washington has grown with its population. Southern representatives have attained powerful leadership positions in both the House of Representatives and Senate, as well as in the White House. These developments have led some to observe that the South is attracting more federal money these days, particularly where congressional leaders are seated (Earle 1998).

Is the South really benefiting more than other regions from federal payments? In this paper, we argue that the answer to this question is both yes and no. In terms of the amount of federal funds received relative to other regions, yes, the South is surpassing the per capita amounts received by other regions. But a close look at the composition and geographic distribution of these funds suggests that the South may not be benefiting as much as the funding totals indicate and, in some respects, federal funding may actually be adding to the South's problems.

This article uses county-level federal funding data from the Bureau of the Census to compute federal funding, per capita, in the South and in other regions. We examine federal funding, by major program function, to distinguish between programs that support primarily national goals with little local benefits other than unintended local economic stimulation (the bacon) and programs that are oriented toward promoting local or regional economic development (the beef). The main question we seek to answer is in which of these program areas, bacon or beef, is the South's basket of federal dollars concentrated?

"Economists at the Economic Research Service, U.S. Department of Agriculture, Washington, D.C. 
Other research questions addressed in this article involve the efficacy and equity of the geographic distribution of federal funds among different types of places within the South. By examining metro and nonmetro areas, focusing particularly on various economic types of nonmetro counties, we identify different types of rural places within the South receiving particularly high or low amounts of federal funds. In some cases, we point out what appear to be mismatches between federal fund receipts and local economic development needs. Correlation analysis between federal funding levels (per capita) and local economic wellbeing (measured by per capita income) addresses the question of whether federal spending adds or detracts from the level of economic inequality among rich and poor counties. Correlations between federal funding levels and county population growth rates shed light on the question of whether federal spending helps mitigate disparities in local growth or whether it adds to local growth and sprawl problems.

\section{DATA AND DEFINITIONS}

Our principal data source is the 1997 Consolidated Federal Funds Reports data from the Bureau of the Census, U.S. Department of Commerce, collected annually from each federal agency. We excluded about 10 percent of federal funds-those programs that cannot be accurately allocated to the county level (mostly state pass-through funds from block grant programs)-so that we could make meaningful interlocal comparisons. ${ }^{1}$ Thus, the totals presented here are somewhat lower than those found elsewhere (U.S. Department of Commerce 1998).

Other data sources include Census' 1990 and 1997 population estimates and 1996 county per capita income estimates from the Bureau of Economic Analysis. We used the four major Census regions (Northeast, Midwest, West, and South) and the 1993 Office of Management and Budget definitions of metropolitan areas (Butler and Beale 1994). For distinctions among nonmetro counties, we used USDA-Economic Research Service (ERS) county typologies (Cook and Mizer 1994).

As explained previously, one of our objectives is to distinguish between programs whose primary benefits are national and programs aimed more at developing local resources for local (or regional) development. For example, a defense plant's output consists of weapons, which, hopefully, are not for local use. Thus the primary economic benefit of the industry-the public good it creates-is nonlocal in nature. Although the plant may provide jobs to some local people, add to the local tax base, and stimulate the local economy, this is a secondary kind of

\footnotetext{
${ }^{1}$ While we cannot say how these excluded funds were allocated among metro and nonmetro areas, in most cases we can identify how they were distributed among the states and regions. Our analysis shows that the South received slightly less of these funds, per capita, than in the rest of the U.S. Overall, the South got $\$ 489$ per capita from the excluded programs, while the U.S. as a whole got $\$ 498$. Most of the excluded funds were income security payments. However, substantial amounts were in national functions and human resources, and in both of these functions the South received about 10 percent less than the U.S. as a whole. The South also received less of the community resources programs that were excluded from this analysis.
} 
benefit, and once the plant is closed, most of the local benefits end. We therefore refer to this as "bacon," implying it has some local economic benefits, but not as much as in some other programs. ${ }^{2}$

In contrast, a program that builds local infrastructure (highways, sewers, telecommunications, airports), provides housing, helps establish or expand local businesses, or enhances the local workforce is referred to here as "beef" because its benefits are primarily local and it is aimed at making a lasting difference in the local economy. ${ }^{3}$ Some programs do not fall nicely into either of these categoriesfor example, Social Security payments benefit local residents but do not enhance the local economy in the same way as infrastructure or human capital investments.

With over 1,000 federal programs, it was not practical to review each program in depth to determine into which category it falls. Consequently, we used ERS's already established definitions for broad functional categories of federal funds to make the following, admittedly imperfect, distinctions. ${ }^{4}$

We defined "bacon" as consisting of two ERS categories of federal spending: the defense and space category and the national functions category (this is an "all other" category that includes higher education and research, energy, criminal justice and law enforcement, nondefense procurement contracts, and nondefense federal wages and salaries).

We defined "beef" as consisting of three ERS categories, all aimed at enhancing local resources (community resources, human resources, and agriculture and natural resources). Community resource programs involve a wide variety of programs, including infrastructure, housing, and business assistance. Human resources programs include education, training, and a wide variety of other programs that invest in people and enhance the long-term capacity of the local labor force. Agricultural and natural resources programs benefit the local

${ }^{2}$ Export base theory (Nijkamp, Rietveld, and Snickars 1986; Bendavid-Val 1991; Mulligan and Vias 1996) argues that this kind of manufacturing plant, which creates a product used outside the local economy, serves as part of the local economic base and not only creates jobs in the defense plant itself, but also stimulates employment and income growth in local nonbase industries (particularly in services industries) with input/output linkages to the plant. In addition, the plant may add to local taxes, which may help pay for local government infrastructure and services that benefit the plant and local economy more generally. However, the local economic benefits of export base development are often limited in rural areas because rural economies themselves tend to be limited, forcing most of the plant's linkages to be located outside the rural community. Even in urban areas, these local benefits may be limited for many types of federal activities. For example, defense procurement often involves substantial subcontracting to plants in other localities. Most military base personnel are recruited nationwide. Finally, many federal suppliers to military bases and other federal facilities are also nonlocal.

${ }^{3}$ All federal programs have national goals, even those described here as "beef." However, in the case of the "beef" programs, the national goals tend to be satisfied largely by achieving local or regional goals, which taken together satisfy national goals. For example, a network of interstate highways is important for the national economy, but such a national network consists of many integrated local and regional networks that are linked together. ${ }^{4}$ ERS's six broad function categories for federal programs are as follows: agriculture and natural resources (agricultural assistance, agricultural research and services, forest and land management, and water and recreation resources); community resources (business assistance, community facilities, community and regional development, environmental protection, housing, Native American programs, and transportation); defense and space (aeronautics and space, defense contracts, and defense payroll and administration); human resources (elementary and secondary education, food and nutrition, health services, social services, and training and employment); income security (medical and hospital benefits, public assistance and unemployment compensation, and retirement and disability-includes Social Security); national functions (criminal justice and law enforcement, energy, higher education and research, and all other programs excluding insurance). 
economy by keeping farms from going under in times of extreme duress and by maintaining or enhancing natural amenities, such as forests, parks, and water resources, which are important to the local quality of life and attract people and jobs to many local areas.

ERS' income security category includes welfare assistance, food stamps, and other programs aimed at helping the poor or unemployed survive in times of need, plus Social Security, Medicare, and other safety net programs. These programs are aimed at improving the well-being of local residents, so they do not fit our "bacon" definition. However, these programs are not really aimed at enhancing the capacity of local resources to further local development, like our "beef" programs. Hence, we considered income security a separate category.

\section{RESULTS}

In fiscal year 1997, the South received $\$ 5,674$ per capita in total federal funds, $\$ 436$ more than the nation as a whole and $\$ 360$ more than the Northeastthe region that ranked second highest in federal funds receipts. The South exceeded the national average in four of the six major program functions (defense and space, human resources, income security, and national functions) and it was within $\$ 7$ per capita of the national average for the other two functions (agriculture and natural resources and community resources) (Table 1). However, the South may not be benefiting as much as these amounts indicate.

TABLE 1

Per Capita Federal Funds by Function and Region, Fiscal Year 1997

\begin{tabular}{|c|c|c|c|c|c|c|c|}
\hline $\begin{array}{l}\text { County } \\
\text { Type }\end{array}$ & $\begin{array}{c}\text { All } \\
\text { Federal } \\
\text { Funds }\end{array}$ & $\begin{array}{l}\text { Agriculture } \\
\text { \& Natural } \\
\text { Resources }\end{array}$ & $\begin{array}{l}\text { Community } \\
\text { Resources }\end{array}$ & $\begin{array}{l}\text { Defense } \\
\text { \& Space }\end{array}$ & $\begin{array}{l}\text { Human } \\
\text { Resources }\end{array}$ & $\begin{array}{l}\text { Income } \\
\text { Security }\end{array}$ & $\begin{array}{c}\text { National } \\
\text { Functions }\end{array}$ \\
\hline \multicolumn{8}{|c|}{ Dollars Per Person } \\
\hline United States & 5,238 & 80 & 508 & 645 & 101 & 3,138 & 767 \\
\hline Metro & 5,333 & 18 & 549 & 734 & 98 & 3,089 & 845 \\
\hline Nonmetro & 4,846 & 302 & 349 & 294 & 113 & 3,329 & 458 \\
\hline South & 5,674 & 73 & 503 & 844 & 108 & 3,214 & 931 \\
\hline Metro & 5,937 & 17 & 570 & 1,033 & 102 & 3,098 & 1,117 \\
\hline Nonmetro & 4,884 & 221 & 307 & 290 & 125 & 3,555 & 385 \\
\hline Northeast & 5,314 & 8 & 438 & 461 & 101 & 3,635 & 672 \\
\hline Metro & 5,369 & 5 & 451 & 457 & 102 & 3,655 & 698 \\
\hline Nonmetro & 4,839 & 28 & 320 & 496 & 93 & 3,457 & 445 \\
\hline Midwest & 4,563 & 131 & 428 & 349 & 86 & 2,988 & 580 \\
\hline Metro & 4,578 & 32 & 475 & 412 & 85 & 2,930 & 644 \\
\hline Nonmetro & 4,522 & 405 & 300 & 174 & 90 & 3,149 & 403 \\
\hline West & 5,131 & 38 & 661 & 799 & 106 & 2,743 & 784 \\
\hline Metro & 5,145 & 16 & 674 & 862 & 101 & 2,707 & 785 \\
\hline Nonmetro & 5,046 & 169 & 582 & 415 & 138 & 2,962 & 779 \\
\hline
\end{tabular}

Note: Individual figures may not sum to total due to rounding.

Source: Calculated by ERS using federal funds data from the Bureau of the Census. 
The South is clearly bringing home a lot of "bacon" - programs whose primary benefits are national. For example, the types of programs that most heavily favor the South relative to other regions are defense and space programs and national functions. These kinds of programs may stimulate local economies where funds are spent, but local economic benefits may be limited in many cases due to limited local economic linkages associated with these federally funded activities. In addition, because these programs are not really designed to stimulate the local economy, they do not necessarily provide what the locality may need most for long-term economic development. Moreover, the funding from these programs tends to be highly concentrated, with most going to metro areas, which as a whole are relatively wealthy and growing rapidly. The nonmetro South, whose economy is more stagnant and might benefit more from the economic stimulus, gets fewer of these "bacon" types of programs than nonmetro areas nationwide, and significantly fewer than metro areas in the South. ${ }^{6}$

The federal programs that most favor the nonmetro South relative to other regions involve income security. This function includes Medicaid, Food Stamps, section 8 public housing assistance, and other programs that help poor people, which are numerous in some parts of the South (mining and poverty counties particularly benefit). However, this function is dominated by programs that benefit retirees, such as Social Security and Medicare, and these programs are of greatest benefit to high-amenity retiree-destination counties in the South. As noted previously, this category of funding is neither "bacon" nor "beef." The inflow of income security funds is clearly important to the nonmetro South, but it does not give state or local officials economic development money to address the region's nonmetro economic problems.

As for the "beef"-programs aimed at enhancing local and regional resources to facilitate economic development-the South does not really stand out from the other regions in receipts from these programs. For example, the West ranks first among the regions in receipt of community resources funding (per capita); the Midwest ranks first in agriculture and natural resources. With respect to the "beef" programs, the South ranks first only in human resources funding, a function involving a relatively small amount of federal funds and for which the regional variations are minimal.

A closer look at where this "beef" goes within the South's nonmetro areas suggests that it may not be going to the places that most need it (Table 2). For example, the South's unskilled, low-wage industries are having trouble competing in today's global economy (Barkley 1999). Moreover, there is general agreement that education and training needs are central to any strategy to upgrade the South's economy, particularly its manufacturing industries (Malecki 1995). Given

\footnotetext{
5In the 1980 s, population in the metro South grew by 20.9 percent, compared to only 3.7 percent in the nonmetro South. From 1990 to 1997, the metro South grew 11.4 percent, compared to 6.9 percent in the nonmetro South (Beale 1999, p. 21).

6In the nonmetro South, total employment grew 10.7 percent from 1990 to 1996, and manufacturing employment grew 2.3 percent. In nonmetro areas outside the South, total employment grew 12.0 percent and manufacturing employment grew 7.7 percent (McGranahan 1999, p. 50).
} 
the relative disadvantage the South has in its high levels of poverty and unskilled labor, southern manufacturing industries might benefit significantly from federal human resources funding. However, nonmetro manufacturing counties ranked last among the nonmetro county types we examined in the South with respect to human resources funding (includes education, training, and other workforce improvement services). ${ }^{7}$ Although our data are lacking for some important programs in this function (particularly in training and child care), this finding might concern policy makers intent on upgrading the southern manufacturing industry. ${ }^{8}$

TABLE 2

Per Capita Federal Funds by Function and Economic County Type, Fiscal Year 1997

\begin{tabular}{|c|c|c|c|c|c|c|c|}
\hline $\begin{array}{l}\text { County } \\
\text { Type }\end{array}$ & $\begin{array}{l}\text { All } \\
\text { Federal } \\
\text { Funds }\end{array}$ & $\begin{array}{l}\text { Agriculture } \\
\text { \& Natural } \\
\text { Resources }\end{array}$ & $\begin{array}{c}\text { Community } \\
\text { Resources }\end{array}$ & $\begin{array}{l}\text { Defense } \\
\text { \& Space }\end{array}$ & $\begin{array}{l}\text { Human } \\
\text { Resources }\end{array}$ & $\begin{array}{l}\text { Income } \\
\text { Security }\end{array}$ & $\begin{array}{c}\text { National } \\
\text { Functions }\end{array}$ \\
\hline \multicolumn{8}{|c|}{ Dollars Per Person } \\
\hline United States & 5,238 & 80 & 508 & 645 & 101 & 3,138 & 767 \\
\hline Metro & 5,333 & 18 & 549 & 734 & 98 & 3,089 & 845 \\
\hline Nonmetro & 4,846 & 302 & 349 & 294 & 113 & 3,329 & 458 \\
\hline South & 5,674 & 73 & 503 & 844 & 108 & 3,214 & 931 \\
\hline Metro & 5,937 & 17 & 570 & 1,033 & 102 & 3,098 & 1,117 \\
\hline Nonmetro & 4,884 & 221 & 307 & 290 & 125 & 3,555 & 385 \\
\hline \multicolumn{8}{|l|}{ By Economic } \\
\hline \multicolumn{8}{|l|}{ County Type: } \\
\hline Farming & 5,017 & 755 & 320 & 94 & 138 & 3,493 & 217 \\
\hline Mining & 5,507 & 83 & 211 & 157 & 142 & 3,911 & 1,003 \\
\hline Manufacturing & 4,316 & 73 & 292 & 172 & 114 & 3,380 & 285 \\
\hline Government & 5,624 & 74 & 374 & 1,254 & 142 & 3,290 & 490 \\
\hline Services & 5,514 & 312 & 336 & 312 & 120 & 4,003 & 430 \\
\hline Nonspecialized & 4,622 & 177 & 308 & 93 & 131 & 3,595 & 318 \\
\hline
\end{tabular}

Note: Individual figures may not sum to total due to rounding.

Source: Calculated by ERS using federal funds data from the Bureau of the Census.

Other southern counties that may particularly require economic development assistance are mining counties. These counties got a fair amount of federal "bacon," particularly from national functions, at \$1,003 per capita. They also received relatively high amounts from income security and human resources programs, which should help their development efforts. However, they got relatively little from community resources and the other two functions. Community

7Manufacturing counties comprise one of the six mutually exclusive economic types developed by Cook and Mizer (1994) for nonmetro counties. These six economic types are defined as follows: 1) farming-dependentfarming contributed a weighted annual average of 20 percent or more of total labor and proprietor income over the 3 years 1987 to $1989 ; 2$ ) mining-dependent-mining contributed a weighted annual average of 15 percent or more of total labor and proprietor income, 1987-89; 3) manufacturing-dependent-manufacturing contributed a weighted annual average of 30 percent or more of total labor and proprietor income, 1987-89; 4) governmentdependent-federal, state, and local government activities contributed a weighted annual average of 25 percent or more of total labor and proprietor income, 1987-89; 5) service-dependent-service activities (private and personal services, agricultural ser-vices, wholesale and retail trade, finance and insurance, real estate, transportation, and public utilities) contributed a weighted annual average of 50 percent or more of total labor and proprietor income, 1987-89; and 6) nonspecialized-counties not classified as a specialized economic type, $1987-89$. ${ }^{8}$ For example, Job Training Partnership Act (recently revised under the Workforce Investment Act) programs, vocational education grants, and child care programs are important for moving people from welfare to work, but they had to be excluded from our analysis because they were block grant programs lacking accurate county data. The largest programs that remained in our analysis in this function were education programs (elementary and secondary aid, school lunch, and Head Start). 
resources, like human resources, are critical for local efforts to diversify the economies in these places, which are suffering from overdependence on declining industries.

Community resources programs are probably the most valuable source of economic development funding, since they include general economic development assistance, business assistance, infrastructure, housing, transportation, and other vital components of economic development strategies. Where does this "beef" go in the South? The answer is metro areas. The metro South ranked second among the four regions in metro receipts from this function, while the nonmetro South ranked last. The difference between metro and nonmetro receipts in the South for this function is a substantial $\$ 263$ per capita, or put another way, the metro South got 85 percent more community resources dollars per capita than the nonmetro South.

How do poor places in the South do in terms of federal funds receipts? One way of answering this question is to examine nonmetro poverty counties (counties with 20 percent or more poverty in each of the last four decennial Censuses) in the South. These counties (not shown in Table 2) received $\$ 5,092$ per capita in total federal funds, more than the nonmetro average, but still below the overall national and regional average (including metro areas). They were about average for nonmetro areas in most functions, but got relatively high amounts for agriculture and natural resources (\$370) and human resources (\$163).

However, our correlation analysis indicated that per capita federal funds tend to be correlated directly (positive correlation) with county per capita income, suggesting that federal spending benefits higher-income places more than lowerincome places (Table 3). ${ }^{9}$ This was true for total federal funds, per capita, and for most of the functions (the main exception was agriculture and natural resources payments). This was not entirely unexpected, because most federal programs are not intended to redistribute income from rich to poor. In fact, some of the largest programs, such as Social Security, are paid out based on how much people pay into the program, thus higher-income areas might be expected to get back higher amounts of income security payments. However, we did not have any reason to expect that higher-income places would receive more than lower-income places in the other functions, like community resources, human resources, defense and space, and national functions.

We also did not expect that the magnitude of the correlations would be so high for the South and its metro areas. For all U.S. metro areas, the correlation coefficient was .13 , about twice that of all nonmetro areas. ${ }^{10}$ In the South, the correlation coefficient for metro areas was .50, while nonmetro areas in the South had

\footnotetext{
${ }^{9}$ This finding may seem inconsistent with our earlier finding that high-poverty counties got more federal funds than other nonmetro counties. The paradox may be explained, in part, by the fact that local poverty rates and per capita incomes are not always highly correlated. For example, one study of nonmetro areas found a correlation of the two indicators to be -.68 in 1985 (Reeder 1990). This suggests the presence of a fair number of counties with both relatively high poverty rates and relatively high average incomes. Another possible explanation for the paradox may lie in the correlation coefficient reflecting variations among nonpoverty counties with different incomes (for example, if high-income counties get significantly more funding than middle-income counties).

${ }^{10}$ The correlation was weaker in nonmetro areas, and we found that nonmetro poverty counties actually got somewhat more federal funds than other types of nonmetro counties.
} 
a correlation coefficient of .28 , which is also high compared with that for nonmetro areas nationwide. Thus, federal spending disproportionately goes to higherincome communities in the South, particularly to higher-income metro areas.

\section{TABLE 3}

Correlation of County Per Capita Federal Funds with

County Per Capita Income and Population Growth Rate,

By Function and Metro Status, Comparing the U.S. with the South

\begin{tabular}{lllll}
\hline & U.S. & South & \\
Federal Funds Function & Total & Metro Nonmetro Total Metro Nonmetro \\
\hline
\end{tabular}

Correlation With Local Per Capita Income ${ }^{a}$

\begin{tabular}{lcccccc} 
Agriculture \& Natural Resources & $(.03)^{\mathrm{b}}$ & $(-.03)$ & .08 & $(.04)$ & $(.07)$ & $(.05)$ \\
Community Resources & .33 & .29 & .19 & .48 & .49 & .23 \\
Defense \& Space & .26 & .24 & .06 & .34 & .36 & .09 \\
Human Resources & .22 & .19 & $(.00)$ & .29 & .31 & .09 \\
Income Security & .33 & .30 & .21 & .46 & .43 & .31 \\
National Functions & .30 & .32 & .10 & .31 & .38 & .16 \\
& & & & & & \\
Total Federal Funds & .06 & .13 & .06 & .47 & .50 & .28 \\
\hline
\end{tabular}

Correlation With Local Population Growth Rate

$\begin{array}{lcccccc}\text { Agriculture \& Natural Resources } & -.07 & (.03)^{\mathrm{b}} & -.08 & (-.03) & (-.02) & (.04) \\ \text { Community Resources } & (-.01) & (.01) & (-.02) & .10 & .08 & .11 \\ \text { Defense \& Space } & (.02) & (-.05) & .06 & (.04) & (.03) & (.03) \\ \text { Human Resources } & (-.01) & (.01) & (-.01) & (-.03) & (-.03) & (.03) \\ \text { Income Security } & -.06 & (-.05) & -.06 & (-.02) & (-.02) & (.02) \\ \text { National Functions } & (.01) & (-.06) & (.03) & (.01) & (.01) & (.00) \\ & & & & & & \\ \text { Total Federal Funds } & -.06 & -.07 & -.06 & (.01) & (-.00) & (.06)\end{array}$

Note: Federal funds data are for fiscal year 1997, income data are for calendar year 1996. Percentage population growth is for 1990 to 1997 . Some "outlier" counties with exceptionally large per capita funds or negative funding amounts (deobligations of funds) for some functions were excluded from the correlation analysis.

aspearman's rho coefficient: 1 equals perfect correlation; 0 equals no correlation. Positive means directly correlated; negative means inversely correlated.

${ }^{b}$ Coefficients in parentheses are not statistically significant from zero at the $5 \%$ probability level.

Source: USDA-ERS analysis using data from the Bureau of Economic Analysis and the Census.

Correlation analysis, however, revealed no strong direct correlation between the rate of county population growth (1990-97) and per capita federal funds receipts. For the U.S. as a whole, a slight inverse correlation was observed, corresponding to agriculture and income security payments. No such overall correlation was observed in the South, though the South exhibited a slight positive correlation associated with community resources programs. This correlation was strongest in the nonmetro South, but was also present in metro areas.

\section{CAVEATS AND CONCLUSIONS}

Before discussing the specific findings and implications, it is useful to note this study's data and methodology limitations. For example, one of our key categories of "beef" programs in which the nonmetro South did particularly well was human resources, a program category that suffered particularly from lack of data. We also lacked county-level data on some important community resources programs, 
such as the state/small cities portion of the Community Block Grant program, the Environmental Protection Agency's Clean Water infrastructure loans, and the Appalachian Regional Commission's programs. Were these data available, we might have altered our conclusions. Further research might be able to make use of other data sources to fill in some of these gaps.

One of the strengths of our analysis is that it aggregates data from many different programs, which simplifies our analysis and allows us to concentrate on separate categories of programs that are thought to have different effects. However, one may always question whether one type of program or another belongs in a particular category. Moreover, aggregating diverse programs together can in some cases be misleading, like adding apples and oranges. We added together grants, loans, wages and salaries, transfer payments, and other types of assistance, though some types of assistance are clearly more valuable than others. For example, grants are obviously more valuable than loans, which must be repaid, while loan programs may outweigh grant programs in some aggregate statistics included in our study. ${ }^{11}$ This suggests that future research might benefit from disaggregating to identify subfunctions of interest. Also, other research methods, such as econometric studies or input-output models, might be usefully employed to help differentiate the impacts of different types of federal programs. ${ }^{12}$ This, however, was beyond the scope of our analysis. ${ }^{13}$

Ignoring these potential limitations, our conclusions should still be of some interest to policy makers in the South because we found that, despite the relatively large per capita levels of federal funds receipts, the South gets much more federal goal-oriented "bacon" than local/regional development-oriented "beef." Both forms of assistance tend to benefit the metro South more than the poorer, stagnant nonmetro South. In addition, our analysis of variations among different types of southern nonmetro counties (we did not look at variations among different metro areas, though that might also be of interest) suggested that the nonmetro places that may be in particular need of economic development "beef," such as manufacturing, mining, and poverty counties, may not be getting sufficient amounts of the assistance they need most.

Some of our findings were surprising. For example, we found that the South's federal dollars are disproportionately going to metropolitan areas-more so than in other regions. This was somewhat surprising because the South is the most rural region in the country, with 30 percent of its population residing in nonmetro areas (Midwest-29 percent, West-16 percent, Northeast-11 percent). With a relatively high percentage of its population residing in rural areas, one might have expected that the South would have more balance among its urban and rural representatives in Congress, which might in turn result in a narrower nonmetro-

\footnotetext{
${ }^{11}$ For example, in the community resources category, housing loans account for about half of the total. If housing loans were distributed substantially differently from the rest of the community resources programs (this was not the case), this could lead to a misleading conclusion about community resource programs in general.

12For an example of a recent econometric effort using federal funds data to estimate the economic impact of federal investments in Appalachia, see Menken (2000).

${ }_{13}$ This article was based on a more comprehensive analysis (Reeder, Bagi, and Calhoun 1999) that included disaggregated funding totals (by major program and function for the U.S. and the South).
} 
metro gap in federal fund receipts. However, a congressperson's legal constituency" is not as important as those supporters who provide organizational and financial resources that help get him or her elected (Romer and Weingast 1991, pp. 181-182). It may be that these supporters in the South may be stronger in metro areas than in nonmetro areas.

Some might argue that this metro-nonmetro gap reflects the "growth center" or "growth pole" strategy that some development organizations in the region-most notably the Appalachian Regional Commission-have pursued. This strategy assumes that it is easier (and less costly) to encourage regional job growth in cities than to create jobs in surrounding rural areas. However, some critics have pointed out that such a growth center approach may make it easier to gain political support for the programs, but it may not actually be effective economically in helping rural residents (Isserman and Rephann 1995, pp. 347-351). Recent empirical studies even question how successful this approach has been in creating growth for the growth centers (Isserman and Rephann 1995, p. 358; Freshwater et al. 1997).

These are just two of many possible explanations for why the South's metro-nonmetro gap exists. ${ }^{14}$ Further research may help us to understand better why this large metro-nonmetro gap exists in the South and what its significance is for the region's economy. Suffice it to say that, at this point, it appears that federal spending is adding to the metro-nonmetro disparities within the region.

Another finding that may be surprising to some is that federal spending is directly correlated with local per capita income-i.e., it benefits higher-income counties more than lower-income counties. While this appears to conflict with the notion that the federal government should help poor places (and people) more than wealthy places (and people), our findings do not necessarily conflict with that concept since our analysis of nonmetro counties found that persistently highpoverty counties received more federal funds per capita than nonmetro counties in general. In addition, much of the redistribution of income from rich to poor is expected to come through the federal tax system rather than through federal spending, which is generally thought to be "spread around." However, our findings indicated that federal spending is not spread around as much in the South as in the rest of the U.S., and wealthier southern places (particularly metro areas, but also some nonmetro areas) appear to be benefiting from this uneven distribution.

Our third interesting, if not surprising, finding is that the geographic pattern of federal spending does not appear to be substantially aggravating growth disparities, either in the U.S. or in the South. In recent years, the issue of urban and rural sprawl has come to the forefront in many policy debates. The federal government is often blamed for contributing to rapid growth and sprawl, if only

\footnotetext{
${ }^{14}$ Another possible explanation is that much of the South's metropolitan funding advantage may be attributed to the presence of the District of Columbia, the seat of the federal government, in the South. To determine how much of the South's metro-nonmetro gap was due to this phenomenon, we recomputed the tables presented in this paper netting out the District's totals. This did reduce the South's metro funding receipts by almost $\$ 300$ per capita (mostly in the form of national functions receipts). However, even without the District, the South's metro areas still received substantially more federal funds than the metro areas in other regions, and the South's metrononmetro funding gap remained substantially larger than in the other regions.
} 
unintentionally, by facilitating the growth through its housing and infrastructure assistance and through other policies, such as regulations and tax incentives (U.S. General Accounting Office 1999). Our analysis found little evidence for this nationwide. Indeed, we found the opposite, that federal spending tended to favor slower-growing places. We also found no evidence that federal spending in general was aggravating growth disparities in the South. However, we did find a slight positive correlation between community resources funding and recent local population growth in the South.

\section{REFERENCES}

Barkley, D.A. "An Overview of Employment Changes in the Nonmetropolitan South." Southern Perspectives 3 (1) (1999), 1-3.

Beale, C.L. "Nonmetro Population Rebound: Still Real but Diminishing." Rural Conditions and Trends 9 (2) (1999), 20-27.

Bendavid-Val, A. Regional and Local Economic Analysis for Practitioners. 4th ed. New York: Praeger, 1991.

Butler, M.A., and C.L. Beale. Rural-Urban Continuum Codes for Metro and Nonmetro Counties, 1993. U.S. Department of Agriculture, Economic Research Service, Staff Report 9425. Washington, D.C., 1994.

Cook, P.J., and K.L. Mizer. The Revised ERS County Typology: An Overview. U.S. Department of Agriculture, Economic Research Service, RDRR 89. Washington, D.C., 1994.

Earle, G. "Power Center: Bridging the Southern Gulf." Congressional Quarterly Weekly 21 November 1998, 3145.

Freshwater, D., T. Wojan, D. Hu, and S. Goetz. "Testing for the Effects of Federal Economic Development Agencies." TVA Rural Studies Staff Paper 97-2, 1997.

Isserman, A., and T. Rephann. "The Economic Effects of the Appalachian Regional Commission: An Empirical Assessment of 26 Years of Regional Development Planning." The Journal of the American Planning Association 61 (3) (1995), 345-364.

Malecki, E.J. "Global Cities and Back Roads: Perspectives on the Southern Economy." The Review of Regional Studies 25 (3) (1995), 239-245.

McGranahan, D.A. "Manufacturing Sector in Black Counties Weakens in Era of New Technology." Rural Conditions and Trends 9 (2) (1999), 48-54.

Mencken, C.F. "Federal Spending and Economic Growth in Appalachian Counties." Rural Sociology 65 (1) (2000), 126-147.

Mulligan, G.F., and A.C. Vias. "An Assessment of the Assignment Method in Economic Base Analysis." The Review of Regional Studies 26 (3) (1996), 265-284.

Nijkamp, P., P. Rietveld, and F. Snickars. "Regional and Multiregional Economic Models: A Survey." In P. Nijkamp (ed.) Handbook of Regional and Urban Economics, Vol. 1: Regional Economics. Amsterdam: North Holland, 1986. 
Reeder, R.J. Targeting Aid to Distressed Rural Areas: Indicators of Fiscal and Community Well-Being. U.S. Department of Agriculture, Economic Research Service, Staff Report 9067. Washington, D.C., 1990.

Reeder, R.J., F.S. Bagi, and S.D. Calhoun. "Federal Funding: How Does the South Measure Up to Other Regions?" Paper presented at the Southern Regional Science Association meetings in Richmond, Virginia, April 15-17, 1999.

Romer, T., and B.R. Weingast. "Political Foundations of the Thrift Debacle." In A. Alesina and G. Carliner (eds.) Politics and Economics in the Eighties. Chicago: University of Chicago Press, 1991.

U.S. Department of Commerce. Federal Expenditures by State for Fiscal Year 1997. Economics and Statistics Administration, Bureau of the Census, FES/97. Washington, D.C., 1998.

U. S. General Accounting Office. Community Development: Extent of Federal Influence on "Urban Sprawl" is Unclear. GAO/RCED-99-87. Washington, D.C., 1999. 